F. med. Genet. (1967). 4, 109.

\title{
Combination of Spherocytosis and a Variant of Beta Thalassaemia ('Isolated Raised $\mathrm{Hb} \mathrm{A}_{2}$ ')
}

\author{
T. A. CUNNINGHAM and F. VELLA \\ From the Departments of Pathology and Biochemistry, College of Medicine, University of Saskatchewan, \\ Saskatoon, Sask., Canada
}

Hereditary spherocytosis is an intrinsic metabolic disorder of erthrocytes characterized by the presence of microcytes and spherocytes in the peripheral blood. It is believed to be due to a derangement in the energy-yielding reactions of glycolysis within the membrane of the erythrocyte. It has been calculated to occur once in every 20,000 births. Though it is not racially restricted, it has been reported most frequently in persons of northern European origin (Harris, 1963).

Beta thalassaemia is a hereditary disturbance in the mechanism of synthesis of the beta polypeptide chain characteristic of the major adult haemoglobin molecular species. It occurs more frequently than spherocytosis, particularly in countries around the Mediterranean littoral and in the Near and the Far East. There are various forms of beta thalassaemia and nearly all of them are characterized by an increase in the $\mathrm{Hb} \mathrm{A}_{2}$ fraction to approximately double the normal level.

One form of beta thalassaemia was described almost simultaneously in Italy by Silvestroni and Bianco (1957) and by Carcassi, Ceppellini, and Siniscalco (1957), in which the increased $\mathrm{Hb} \mathrm{A_{2 }}$ concentration was not associated with the usual abnormal morphological characteristics of the erythrocytes, and which appeared to be transmitted as a Mendelian dominant character. Similar findings have been reported in Greek subjects (Gouttas 1962) and in a British family (Callender, Mallett, and Lehmann, 1961). This variant has been reported in three genetic forms: heterozygous, presumed homozygous, and in combination with classical beta thalassaemia (Silvestroni and Bianco, 1966; Quattrin, Dini, and Ventruto, 1964). It has been variously described as: 'elevated $A_{2}$ haemo-

Received November 8, 1966. globin without morphologic thalassaemia' (Bannerman, 1961), 'beta chain thalassaemia in absence of a thalassaemia-like picture' (Fessas, 1965), 'isolated increase of haemoglobin $\mathrm{A}_{2}$ ' (Silvestroni and Bianco, 1966), and 'elevated $\mathrm{Hb} \mathrm{A}_{2}$ without microcythaemia' (Quattrin et al., 1964). According to Quattrin et al., this form accounts for $8 \%$ of all the thalassaemias found around Naples (Italy), though the frequency in Greece appears to be less than this (Gouttas, 1962). Weatherall (1965), however, considers it unlikely that this condition represents a separate genetic entity, and thinks of it as 'rather one extreme of the continuous clinical variation from complete normality to a picture of severe thalassaemia, which seems to characterize heterozygous beta thalassaemia'. It is useful, for descriptive purposes, to consider an isolated raised $\mathrm{Hb} \mathrm{A}_{2}$ concentration as a distinct clinical form of beta thalassaemia.

The hereditary anomalies characteristic of spherocytosis and of beta thalassaemia affect different biochemical systems in the developing erythroblast. It is not surprising, that the genes concerned are not allelic and appear not to be closely linked. The occurrence of these genes in combination, though theoretically possible, must in practice be uncommon. There is only one published report in which the combination of spherocytosis, $\mathrm{Hb} \mathrm{S}$, and an unusual form of thalassaemia have been presumed to occur together in a Negro woman (Cohen, Zuelzer, Neel, and Robinson, 1959). In this patient the thalassaemia variant which was postulated produced the characteristic erythrocyte morphology but not the increase in $\mathrm{Hb} \mathrm{A}_{2}$. This gave rise to the concept of a 'non-interacting' form of thalassaemia. The suggestion was also made that the expression of this thalassaemia gene was masked by the presence of the gene for spherocytosis.

We would like to record the finding of spherocytosis and a raised $\mathrm{Hb} \mathrm{A}_{2}$ level, in the absence of the 
morphological characteristics of thalassaemia, in a white subject. This is the first description of this combination of hereditary intra-erythrocytic defects.

\section{Case Report}

A man, 28 years old, was born in Jordan of Syrian parents and immigrated to Canada in 1958. His father and mother are alive and well, and an only brother is now 17 years old.

The patient was admitted into University Hospital, Saskatoon, for submucous resection of the nasal septum. He had complained of bouts of nasal bleeding and generalized headaches. There was no past history of jaundice, anaemia, allergy, or surgical operation. On physical examination his nasal septum was found to be deviated to the right. There were no physical or functional abnormalities, though the spleen was just palpable but not tender.

Laboratory Investigations. $\mathrm{Hb} 15.6 \mathrm{~g} . / 100 \mathrm{ml}$, WBC $6400 / \mathrm{mm}^{3}$, platelets $113,000 / \mathrm{mm}^{3}{ }^{3}$ Reticulocytes $0.9 \%$, ESR $7 \mathrm{~mm}$. Bleeding time $1 \mathrm{~min}$. $30 \mathrm{sec}$., clotting time (Lee and White three tube method) $19 \mathrm{~min}$. $32 \mathrm{sec}$. Quick's prothrombin time $14 \mathrm{sec}$. (control 14 sec.). Clot retraction incomplete. Thrombin titre: 1/64 (control 1/64). Hicks Pitney partial thromboplastin time $38 \mathrm{sec}$. (control $37 \mathrm{sec}$.). Direct Coombs test negative. LE cells negative. Peripheral blood smears showed distinct microcytosis and spherocytosis, but slight anisocytosis and polychromasia. The osmotic fragility curve was shifted to the left both with and without incubation. Total bilirubin $0.7 \mathrm{mg}$. $/ 100 \mathrm{ml}$. $X$ ray films of the chest were normal. Urinalysis gave normal results.

A submucous resection of the septum was carried out. There was some bleeding and oozing after operation and a haematoma developed on the left side of the septum posteriorly. The pathological report on the resected material read 'degenerating osseous and cartilaginous tissue from the nasal septum'.

Special Investigations. Electrophoresis of the haemoglobin was performed on filter paper using a TrisEDTA-borate/veronal discontinuous buffer system ( $p \mathrm{H}$ 8.6) and on starch gel using Tris-EDTA borate buffer at the same $p \mathrm{H}$. Both methods showed $\mathrm{Hb} \mathrm{A}_{1}$ and a marked $\mathrm{Hb} \mathrm{A}$ band. Elution of the $\mathrm{Hb} \mathrm{A}_{2}$ from a starch block after electrophoresis at alkaline $p \mathrm{H}$ showed it to account for $5.4 \%$ of the total haemoglobin. The 'one minute alkali denaturation test' for foetal haemoglobin gave normal results.

Family Study. The only relative available for study was the patient's brother. He was in good health. Laboratory investigations on him showed: Hb 16.2 g./ $100 \mathrm{ml}$., PCV 50\%, RBC 5.0 million $/ \mathrm{mm}^{3}$ Prothrombin time $12 \mathrm{sec}$. (control $13 \mathrm{sec}$ ), thrombin titre $1 / 64$ (control 1/64), Hicks Pitney partial thromboplastin time 39 sec. (control $39 \mathrm{sec}$.). Peripheral blood smears showed no morphological abnormality. Osmotic fragility curves with and without incubation were within normal limits. $\mathrm{Hb}$ electrophoresis showed the $\mathrm{A}_{2}$ fraction to amount to $5 \%$, while foetal $\mathrm{Hb}$ was normal.

\section{Discussion}

The diagnosis of hereditary spherocytosis in our patient was based on: (1) the presence of spherocytes in peripheral blood smears, (2) the increased osmotic fragility of the erythrocytes both with and without incubation, (3) the absence of any evidence of acquired haemolytic disease. The mild degree of reticulocytosis, the normal total bilirubin concentration, and the spleen, which was just palpable, suggested that any haemolysis taking place was minimal. The diagnosis of beta thalassaemia was based on the finding of an abnormal amount of $\mathrm{Hb} \mathrm{A}$.

There are several features of interest in our patient.

(1) The mildness-virtually complete absenceof symptoms attributable to either of the two inherited anomalies: the thalassaemia component would have been missed if electrophoretic studies on the $\mathrm{Hb}$ had not been carried out.

(2) The absence of any morphological characteristics of the erythrocytes attributable to thalassaemia in the patient's brother: this suggests that the morphological abnormalities (microcytosis, mild anisocytosis, and mild polychromasia) in the patient's erythrocytes were due to the spherocytosis component.

(3) The lack of any clinical or laboratory evidence of interaction between the two intra-erythrocytic defects or of accentuation of the pathogenicity of either.

(4) The prolonged clotting time.

There are reports of the combination of hereditary spherocytosis with a number of other hereditary anomalies of the erythrocyte. Thus, the combination of spherocytosis and sickling is well known (Cohen et al., 1959; Smith and Conley, 1954; De Torregrosa, Ortiz, and Vargas, 1956; Jones and Klingberg, 1959; Martin, Kough, and Branche, 1959; Whitaker, Windmiller, Vietti, and Sartain, 1963). The simultaneous presence of three erythrocytic defects (spherocytosis, haemoglobin C, and sickling) has been found in one family (Thompson and Robertson, 1964), while the combination of spherocytosis, sickling, and an unusual variety of thalassaemia was presumed present in a Negro woman (Cohen et al., 1959). It has been established for several years that haemoglobins $S$ and $C$ are beta polypeptide chain variants of normal adult 
$\mathrm{Hb}$ and the reports of the simultaneous presence of these two haemoglobins together with spherocytosis demonstrate that spherocytosis is not allelic with the locus for the beta polypeptide chain of haemoglobin. The findings in our patient also suggest that the genes for spherocytosis and for the beta thalassaemia variant present in him are non-allelic.

There is no evidence that the simultaneous presence of the genes for spherocytosis and the beta thalassaemia variant in our patient in any way interfered with the expression or clinical manifestation of either. A similar lack of interaction can be inferred from study of the published reports on patients with the combination of hereditary elliptocytosis and classical beta thalassaemia (Brumpt, Delabarre, and De Traverse, 1960; De Vries, De Jong, and Frenkel, 1959; Aksoy, 1963; Perillie and Chernoff, 1965).

Absence of the haematological stigmata of a postulated thalassaemia gene in the presence of spherocytosis was noted by Cohen et al. (1959) in their patient. This they attributed to a suppression or masking of the thalassaemia effect, by the spherocytosis gene. However, the thalassaemia gene they postulated did not produce an increase in haemoglobin $A_{2}$ level. In our patient this explanation is not tenable since his brother also had a raised haemoglobin $\mathrm{A}_{2}$ level in the absence of any noticeable morphological abnormalities. The thalassaemia gene in our family, therefore, is of the kind that is expressed as an isolated raised haemoglobin $\mathrm{A}_{2}$ level.

No explanation can be offered for the finding of a prolonged clotting time and incomplete clot retraction in our patient. There was no history of a haemorrhagic diathesis in the patient or his family. The situation is different, therefore, from that reported by Chatterjea (1956) in a Hindu family in which both spherocytosis and 'pseudo haemophilia' were present and occurred together in one member.

\section{Summary}

A case report is presented of a male Jordanian of Syrian origin in whom the combination of spherocytosis and a beta thalassaemia variant (isolated raised haemoglobin $A_{2}$ level) occurred. This is the first description of this combination of hereditary intrinsic abnormalities of the erythrocyte. There was no evidence of interaction between the two genes. The genetic combination was asymptomatic and was discovered during routine pre-operative investigation.

This work is supported by a grant from the Medical Research Council of Canada to F. V.

\section{REFERENCES}

Aksoy, M. (1963). The combination of hereditary elliptocytosis with heterozygous beta thalassaemia. Acta haemat. (Basel), 30, 215.

Bannerman, R. M. (1961). Thalassemia: A Survey of Some Aspects, p. 53. Grune and Stratton, New York.

Brumpt, L. C., Delabarre, L. C., and De Traverse, P. M. (1960). Double hétérozygotie entre thalassémie et elliptocytose. In Proc VIIth Congr. int. Soc. Hemat., Vol. 2, Pt. 1, p. 451. Pensiero Scientifico, Rome.

Callender, S. T., Mallett, B. J., and Lehmann, H. (1961). Thalassaemia in Britain. Brit. F. Haemat., 7, 1.

Carcassi, U., Ceppellini, R., and Siniscalco, M. (1957). Il tracciato elettroforetico dell' emoglobina per una migliore discriminazione delle talassemie. Haematologica, 42, 1635.

Chatterjea, J. B. (1956). Hereditary spherocytosis with 'pseudohaemophilia'. Bull. Calcutta Sch. trop. Med., 4, 90.

Cohen, F., Zueizer, W. W., Neel, J. V., and Robinson, A. R. (1959). Multiple inherited erythrocyte abnormalities in an American negro family; Hereditary spherocytosis, sickling and thalassemia. Blood, 14, 816.

De Torregrosa, M. V., Ortiz, A., and Vargas, D. (1956). Sickle cell-spherocytosis associated with hemolytic anemia. ibid., 11, 260.

De Vries, S. I., De Jong, J., and Frenkel, M. (1959). Anemie elliptocytaire hemolytique. Schweiz. med. Wschr., 89, 1078.

Fessas, P. (1965). Forms of thalassaemia. In Abnormal Haemoglobins in Africa, ed. J. H. P. Jonxis, p. 71. Blackwell, Oxford.

Gouttas, A. (1962). Les expressions du gene thalassemique en Grece. In Haemoglobin-Colloquium, ed. H. Lehmann and K. Betke, p. $89 . \quad$ Thieme, Stuttgart.

Harris, J. W. (1963). The Red Cell, p. 252. Harvard University Press, Cambridge, Massachusetts.

Jones, B., and Klingberg, W. G. (1959). Haemoglobin S-hereditary spherocytosis. $\mathcal{F}$. Pediat., 54, 375.

Martin, W. W., Kough, R. H., and Branche, G. C. (1959). Hereditary spherocytosis-sicklemia in the negro. Blood, 14, 688.

Perillie, P. E., and Chernoff, A. I. (1965). Heterozygous betathalassemia in association with hereditary elliptocytosis. ibid., 25, 494.

Quattrin, N., Dini, E., and Ventruto, V. (1964). Two new thalassaemic syndromes. (a) Homozygous alpha-thalassaemia, (b) Cooley-like disease due to homozygous elevated $\mathrm{Hb}$ A2 without microcythaemia. Acta haemat. (Basel), 32, 221.

Silvestroni, E., and Bianco, I. (1957). Sull' esistenza nella popolazione italiana di soggetti non microcitemici portatori di un' elevata quota di emoglobina adulta lenta $\left(\mathrm{Hb} \mathrm{A}_{2}\right.$ ) e sui loro rapporti con i malati di anemia microcitica. Policlinico, Sez. prat., 64, 1868.

- and - (1966). Pluralità delle microcitemie (o thalassemie). ibid., 73, 41.

Smith, E. W., and Conley, C. L. (1954). Clinical features of the genetic variants of sickle cell disease. Bull. Fohns Hopk. Hosp., 94, 289.

Thompson, R. B., and Robertson, M. G. (1964). Three inherited intraerthrocytic defects: Hereditary spherocytosis, $\mathrm{Hb} \mathrm{S}$ and Hb C. Acta haemat. (Basel), 32, 233.

Weatherall, D. J. (1965). Thalassaemia Syndromes, p. 69. Blackwell, Oxford.

Whitaker, J. A., Windmiller, J., Vietti, J., and Sartain, P. (1963). Hereditary spherocytosis associated with sickle cell trait and cholelithiasis. F. Pediat., 63, 65. 